\title{
CHOP induces death by promoting protein synthesis and oxidation in the stressed endoplasmic reticulum
}

\author{
Stefan J. Marciniak, ${ }^{1}$ Chi Y. Yun, ${ }^{1}$ Seiichi Oyadomari, ${ }^{1}$ Isabel Novoa, ${ }^{1}$ Yuhong Zhang, ${ }^{1}$ \\ Rivka Jungreis, ${ }^{1}$ Kazuhiro Nagata, ${ }^{2}$ Heather P. Harding, ${ }^{1}$ and David Ron ${ }^{1,3}$ \\ ${ }^{1}$ Skirball Institute of Biomolecular Medicine and the Departments of Cell Biology, Medicine and Pharmacology, New York \\ University School of Medicine, New York, New York 10016, USA; ${ }^{2}$ Institute for Frontier Medical Sciences Kyoto \\ University, Kyoto 606-8397, Japan
}

\begin{abstract}
Unfolded and malfolded client proteins impose a stress on the endoplasmic reticulum (ER), which contributes to cell death in pathophysiological conditions. The transcription factor C/EBP homologous protein (CHOP) is activated by ER stress, and $\mathrm{CHOP}$ deletion protects against its lethal consequences. We find that $\mathrm{CHOP}$ directly activates GADD34, which promotes ER client protein biosynthesis by dephosphorylating phosphoSer 51 of the $\alpha$-subunit of translation initiation factor 2 (eIF2 $\alpha$ ) in stressed cells. Thus, impaired GADD34 expression reduces client protein load and ER stress in $\mathrm{CHOP}^{-/-}$cells exposed to perturbations that impair ER function. $\mathrm{CHOP}^{-/-}$and $\mathrm{GADD} 34$ mutant cells accumulate less high molecular weight protein complexes in their stressed ER than wild-type cells. Furthermore, mice lacking GADD34-directed eIF2 $\alpha$ dephosphorylation, like $\mathrm{CHOP}^{-/-}$mice, are resistant to renal toxicity of the ER stress-inducing drug tunicamycin. $\mathrm{CHOP}$ also activates ERO1 $\alpha$, which encodes an ER oxidase. Consequently, the ER of stressed $\mathrm{CHOP}^{-/-}$cells is relatively hypo-oxidizing. Pharmacological and genetic manipulations that promote a hypo-oxidizing ER reduce abnormal high molecular weight protein complexes in the stressed ER and protect from the lethal consequences of ER stress. CHOP deletion thus protects cells from ER stress by decreasing ER client protein load and changing redox conditions within the organelle.
\end{abstract}

[Keywords: Protein folding; chaperones; membranes; secretion; protein phosphorylation; gene expression]

Supplemental material is available at http://www.genesdev.org.

Received August 17, 2004; revised version accepted October 14, 2004.

Newly synthesized proteins translocated into the lumen of the endoplasmic reticulum (ER client proteins) are folded, post-translationally modified, assembled into oligomeric complexes, and ultimately exported. This load, which can be very heavy in secretory cells, imposes a physiological ER stress that is counteracted by a stereotyped set of adaptations collectively known as the unfolded protein response (UPR) (Patil and Walter 2001; Harding et al. 2002; Kaufman 2002). The UPR adapts the capacity of the secretory system to the load of client proteins by transcriptional up-regulation of genes that function in all aspects of ER client protein processing and metabolism. The UPR also transiently attenuates client protein synthesis, reducing the load on the organelle; but ultimately, the cell strives to defend and promote physiological levels of secretory activity. The importance of the UPR to secretory cell homeostasis is re-

${ }^{3}$ Corresponding author.

E-MAIL ron@saturn.med.nyu.edu; FAX (212) 263-8951.

Article and publication are at http://www.genesdev.org/cgi/doi/10.1101/ gad.1250704. vealed by the phenotype of mutations affecting UPR signaling; these are associated with enhanced cell death and with defective secretory capacity (Harding et al. 2000b, 2001; Scheuner et al. 2001; Shen et al. 2001; Zhang et al. 2002).

Death is also conspicuous in cells with a normally functioning UPR that have encountered insurmountable ER stress. Thus, exposure to the glycosylation inhibitor tunicamycin, to calcium ionophores that deplete ER calcium stores, or to reducing agents such as dithiothreitol that block disulfide bond formation all lead to ER stress and cell death (Kaufman 1999). Even more informative is the phenotype of certain toxic gain-of-function mutations that compromise the folding of abundantly expressed ER client proteins and lead to death of the producing cell. Examples include the $\mathrm{C} 92 \rightarrow \mathrm{Y}$ mutation in insulin 2 in the Akita mouse model of early onset Diabetes Mellitus (Oyadomari et al. 2002b) and mutations affecting the folding of myelin constituents that lead to oligodendrocyte death (Gow et al. 1998).

These pharmacological models and rare diseases point to the potential lethal consequences of ER stress. ER 
stress also accompanies common pathophysiological conditions, such as tissue ischemia (Paschen and Doutheil 1999; Kumar et al. 2001), viral infection (Jordan et al. 2002; Su et al. 2002), free cholesterol loading of macrophages in atherosclerotic lesions (Feng et al. 2003), and even $\beta$-cell exhaustion in Diabetes Mellitus (Oyadomari et al. 2002a). Various downstream effectors of cell death induced by ER stress have been identified (Nakagawa et al. 2000; Rao et al. 2001; Wei et al. 2001); however, the proximal steps that mobilize them during ER stress are poorly understood.

The C/EBP homologous protein (CHOP, also known as GADD153) is a transcription factor that is activated at multiple levels during ER stress. The ER stress-activated kinase PERK phosphorylates the $\alpha$ subunit of eukaryotic translation initiation factor $2(\mathrm{eIF} 2 \alpha)$, and the attendant decrease in eIF2 activity paradoxically activates the translation of the ATF4 mRNA, whose encoded protein binds to and activates the CHOP promoter (Fawcett et al. 1999; Harding et al. 2000a; Ma et al. 2002). The CHOP promoter also receives positive input from other components of the UPR (Wang et al. 1998b; Yoshida et al. 2000), and CHOP protein is post-translationally activated by the p38 kinase (Wang and Ron 1996). Deregulated CHOP activity compromises cell viability (Zhan et al. 1994; Friedman 1996; McCullough et al. 2001), and cells lacking $C H O P$ are significantly protected from the lethal consequences of ER stress (Zinszner et al. 1998; Oyadomari et al. 2002b).

It is likely that CHOP sensitizes cells to ER stressmediated death by directly regulating target genes in the nucleus, as mutations affecting dimerization or DNA binding neutralize CHOP (Ubeda et al. 1996; McCullough et al. 2001). However, the identities of these target genes and the manner by which they might be related to death of ER stressed cells remain unknown. We have used expression profiling to identify potential CHOP target genes and have explored the leads provided by this analysis to better characterize the phenotype of $C H O P$ knockout cells and animals. We report here on the surprising observation that $C H O P$ target genes promote ER client protein load and an oxidative environment in the organelle. Thus, $\mathrm{CHOP}^{\prime}$ s role in the death of ER-stressed cells is better explained by its proximal effects on ER function than by distal interactions with the cell-death machinery. These findings have important implications for the function of the mammalian UPR.

\section{Results}

A kinetic delay in the $\mathrm{CHOP}^{-/-} U P R$ and identification of potential CHOP target genes

Transcriptional profiling was used to compare the complement of mRNAs in unstressed and ER-stressed wild-type and $\mathrm{CHOP}^{-/-}$primary mouse embryo fibroblasts (MEFs). As noted previously (Harding et al. 2003; Murray et al. 2004), exposure of cells to tunicamycin, a glycosylation inhibitor that perturbs protein folding in the ER, progressively induced a large number of genes (206), while expression of a smaller number of genes was significantly repressed. While most of the genes induced by tunicamycin in the wild-type cells were eventually induced to wild-type levels in the $\mathrm{CHOP}^{-/-}$mutant cells, there was a noticeable delay in the induction of this entire set of UPR target genes in the mutant cells, which is readily apparent by comparing the expression profiles in the two genotypes at the intermediate 4 -h time point (Fig. 1).

The induction of a much smaller group of genes was impaired in the mutant cells at both time points. This group of 26 genes (Supplementary Table 1), which passed strict statistical criteria, included $C H O P$ itself and the previously identified CHOP target gene CA6 (Wang et al. 1998a), validating the experimental results. Among these 26 genes were at least two known UPR targets with a potential to affect ER function globally. ERO1 $\alpha$ encodes the mammalian homolog of a yeast ER oxidase, ERO1, which promotes disulfide bond formation (for review, see Frand et al. 2000; Tu and Weissman 2004). $G A D D 34$ encodes a regulatory subunit of an eIF $2 \alpha$-directed phosphatase complex that promotes recovery of

A

12,488 GENES

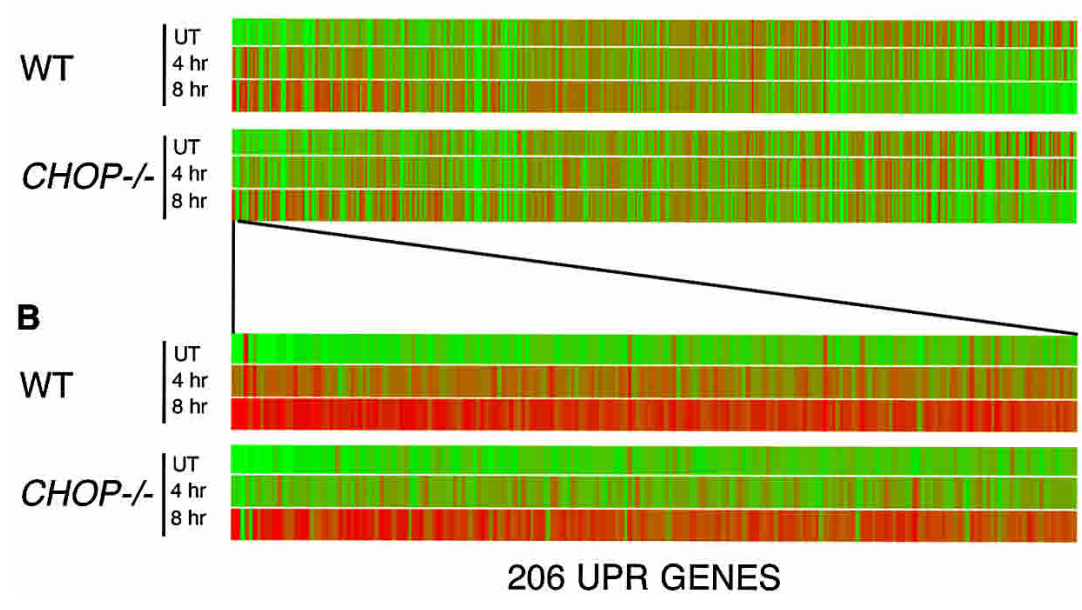

Figure 1. Transcriptional profiling reveals a slowed induction of the UPR and specific gene defects in $\mathrm{CHOP}^{-/-}$fibroblasts. $(A)$ Graphic representation of the average expression $(n=4)$ level of 12,488 genes in untreated and tunicamycin-treated, wild-type and $\mathrm{CHOP}^{-/-}$MEFs. Each vertical bar represents a single gene. Green coloration indicates relatively low levels of expression, and red indicates a relatively high level of expression of a given mRNA. (B) Expansion of the cluster of 206 genes significantly activated by tunicamycin in either wild-type or $\mathrm{CHOP}^{-/-}$cells. The genes are arranged (left to right) by descending order of inducibility by tunicamycin in the wild-type sample at the 8 -h time point. 
protein synthesis in cells exposed to ER stress (Connor et al. 2001; Novoa et al. 2001, 2003; Brush et al. 2003). The kinetic delay in the UPR gene-expression profile could be due to attenuated development of ER stress in the $\mathrm{CHOP}^{-/-}$mutant cells or to defective signaling in the UPR. We designed experiments to distinguish between these possibilities and to examine the role of GADD34 and ERO1 $\alpha$ as CHOP effectors.

Both the dose response and time course of BiP induction by tunicamycin were shifted to the right in the $\mathrm{CHOP}^{-/-}$cells (Fig. 2A,B), consistent with the expression array experiment. Relative resistance to the effects of tunicamycin could provide a trivial explanation for the delayed UPR in the $C H O P^{-/-}$cells. Therefore, we compared the synthesis of glycoslylated and nonglycosylated forms of an endogenous, sentinel, glycoprotein, Hsp47, following treatment with tunicamycin. Tunicamycin decreased the synthesis of the slower migrating glycosylated form of Hsp47 and increased the synthesis of the faster migrating nonglycosylated form equally in wildtype and $\mathrm{CHOP}^{-/-}$MEFs (Fig. 2C).

To distinguish between attenuated development of ER stress and attenuated signaling in the UPR in the $\mathrm{CHOP}^{-/-}$cells, we measured the activity of an upstream UPR marker. ER stress activates the IRE1 kinase-endoribonuclease to process, post-transcriptionally its effector mRNA. In mammals, this results in excision of a 26nucleotide segment of the XBP-1 mRNA, which can be revealed by a simple PCR assay. The excision, or splicing event, is a direct reflection of IRE1 activity (Yoshida et al. 2001; Calfon et al. 2002); therefore, the ratio of spliced to unspliced XBP-1 mRNA serves as a proximal reporter on the level of ER stress. A detailed time course shows that XBP-1 splicing integrated over the time course of the experiment is reproducibly lower in the $\mathrm{CHOP}^{-/-}$ cells (Fig. 2D). Incomplete splicing observed at the later time points is unlikely to reflect acquired failure of IRE1 signaling, as splicing was readily induced by a second stress delivered to the mutant cells (Supplementary Fig. S1). These observations suggest that $\mathrm{CHOP}^{-/-}$cells experience less ER stress than wild-type cells.

\section{CHOP-mediated activation of GADD34 enhances client protein synthesis and the formation of a HMW detergent-resistant stress-associated ER complex}

$G A D D 34$ encodes a regulatory subunit of an eIF $2 \alpha$-specific phosphatase complex that promotes translational recovery from the early phase of translational repression, common to a variety of stress responses, including the UPR. GADD34 is itself a target gene of the UPR, and its induction in the UPR depends on the ER stress-inducible eIF2 $\alpha$ kinase PERK (Novoa et al. 2001), on eIF2 $\alpha$ phosphorylation (Lu et al. 2004), and on the consequent translational activation of ATF4 (Ma and Hendershot 2003). The last two steps, which are also triggered by other stress pathways, constitute an integrated stress response, which activates $C H O P$, among other genes. Unlike most UPR target genes, whose expression was ultimately induced to wild-type levels in tunicamycin-treated

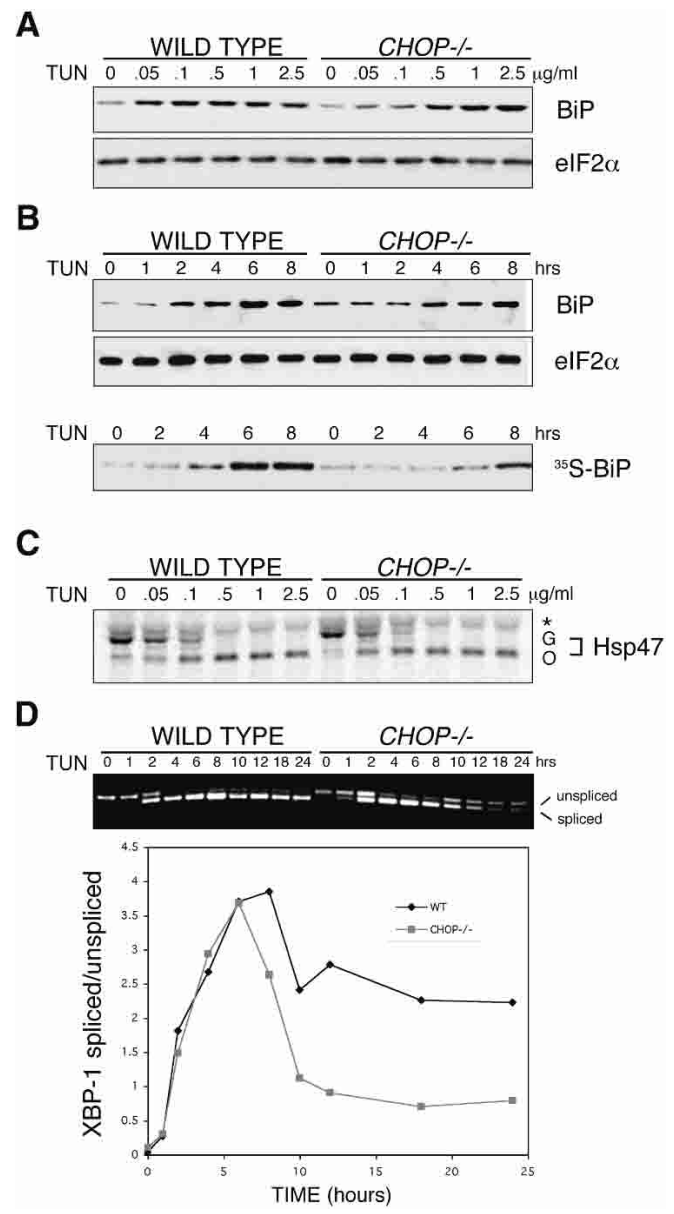

Figure 2. Lower levels of ER stress in tunicamycin-treated $\mathrm{CHOP}^{-/-}$cells. (A) Immunoblots of BiP and eIF2 $\alpha$ (a loading control) from wild-type and $\mathrm{CHOP}^{-/-}$cells treated with varying doses of tunicamycin for $6 \mathrm{~h}$. (B) Immunoblots as in $A$ of cells treated with $0.5 \mu \mathrm{g} / \mathrm{mL}$ tunicamycin for the indicated period of time (top two panels) and autoradiograph of immunoprecipitated newly synthesized $\left.{ }^{35} \mathrm{~S}\right] \mathrm{BiP}$ following pulse labeling of the treated cells (bottom). (C) Autoradiograph of ${ }^{35}$ S-labeled Hsp47 immunoprecipitated from wild-type and $\mathrm{CHOP}^{-/-}$cells briefly pulsed with $\left[{ }^{35} \mathrm{~S}\right]$ methionine after $1 \mathrm{~h}$ of exposure to the indicated concentration of tunicamycin. The position of the glycosylated $(\mathrm{G})$ and nonglycosylated $(\mathrm{O})$ forms of Hsp47 on the SDSPAGE are indicated. Also indicated is an irrelevant band immunoprecipitated by the anti-Hsp47 antiserum $\left({ }^{*}\right)(D)$ Ethidium bromide-stained gel of unspliced and IRE1-spliced XBP-1 RTPCR product (reporting on mRNA) following a time course of tunicamycin treatment $(0.5 \mu \mathrm{g} / \mathrm{mL})$. The ratio of spliced/unspliced RNA in each sample in the two genotypes is also presented graphically.

$\mathrm{CHOP}^{-/-}$cells, GADD34 mRNA levels remained reduced in the stressed mutant cells (Supplementary Table 1). GADD34 immunoblot revealed a pervasive defect in induction of the protein in the $\mathrm{CHOP}^{-/-}$cells. Furthermore, the sustained increase in eIF $2 \alpha$ phosphorylation observed in the stressed mutant cells (Fig. 3A) was consistent with a dephosphorylation defect, as normally, $G A D D 34$ induction early in the stress response promotes subsequent dephosphorylation of eIF2 $\alpha$ (Novoa et al. 2003). 
A

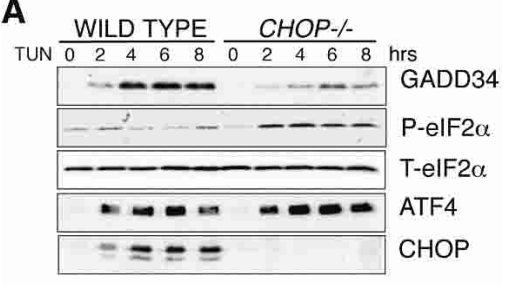

B

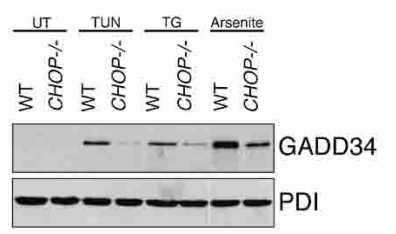

C

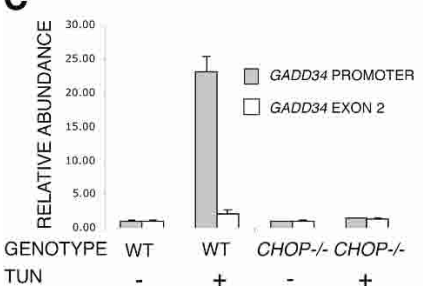

Figure 3. Impaired induction of GADD34 in $\mathrm{CHOP}^{-/-}$cells leads to persistent eIF2 $\alpha$ phosphorylation during stress. $(A)$ Immunoblot of GADD34, phosphorylated eIF2 $\alpha$ (P-eIF2 $\alpha)$, total eIF $2 \alpha$ (T-eIF2 $\alpha$ ) ATF4, and CHOP from lysates of tunicamycintreated wild-type and $\mathrm{CHOP}^{-/-}$cells. (B) Immunoblot of GADD34 and PDI (a loading control) from lysates of wild-type and $\mathrm{CHOP}^{-/-}$cells, exposed to $2 \mu \mathrm{g} / \mathrm{mL}$ tunicamycin, $400 \mathrm{nM}$ thapsigargin, $25 \mu \mathrm{M}$ arsenite, or untreated (UT). (C) Chromatin immunoprecipitation of GADD34 with anti-CHOP antiserum from untreated and tunicamycin-treated $(2 \mu \mathrm{g} / \mathrm{mL}, 8 \mathrm{~h})$ wildtype and $\mathrm{CHOP}^{-/-}$cells detected by a quantitative genomic PCR targeting the promoter region or exon 2 of GADD34. The signal in the untreated $\mathrm{CHOP}^{-/-}$cells was arbitrarily assigned a value of 1 .

GADD34 induction by other stressors that activate the eIF $2 \alpha$ phosphorylation-dependent integrated stress response was also attenuated in the $\mathrm{CHOP}^{-/-}$cells (Fig. 3B), suggesting a broad role for CHOP in GADD34 induction. As CHOP activates gene expression by binding to cis-acting DNA elements in promoter regions (Ubeda et al. 1996; Sok et al. 1999), we attempted to immunoprecipitate the GADD34 promoter in a complex with CHOP from the nuclei of stressed cells following gentle cross-linking of the putative complex in vivo. Quantitative genomic PCR using primers directed to a proximal segment of the GADD34 promoter (which contains a putative $\mathrm{CHOP}$-binding site), revealed that $\mathrm{CHOP}$ antisera immunoprecipitated the GADD34 promoter fragment from stressed wild-type cells, but not from unstressed wild-type cells or from stressed $\mathrm{CHOP}^{-/-}$cells (Fig. 3C). This chromatin immunoprecipitation experiment suggests that GADD34 is a direct CHOP target gene.

The above suggested that CHOP-mediated GADD34 induction might play a role in translational recovery from ER stress. To test the prediction that stressed wildtype (CHOP-expressing) cells would recover synthesis more rapidly and thus synthesize more ER client protein than stressed $\mathrm{CHOP}^{-/-}$cells, we pulse-labeled cells with $\left[{ }^{35} \mathrm{~S}\right]$ methionine at various times after induction of ER stress, purified microsomes, and resolved the radiolabeled, newly synthesized proteins by SDS-PAGE. For these experiments, we chose to treat the cells with thapsigargin, which induces ER stress more rapidly and synchronously than tunicamycin (Bertolotti et al. 2000). Microsome-associated translation recovered to $38 \%$ of baseline by $6 \mathrm{~h}$ in the wild-type cells, whereas $\mathrm{CHOP}^{-/-}$ cells experienced a sustained reduction in new protein synthesis, recovering to only $16 \%$ of baseline (Fig. 4A).

To determine the state of newly synthesized microsomal proteins in wild-type cells during their recovery from translational attenuation, we subjected the detergent-solubilized radiolabeled proteins to velocity gradient centrifugation. Interestingly, this revealed a significant fraction of radiolabeled proteins that sedimented rapidly to the bottom of the gradient, indicating that they are part of very large, megadalton-sized complex(es) (Fig. 4B). Among the prominent constituents of this high molecular weight (HMW) material was a $78-\mathrm{kDa}$ protein, which comigrated with the ER chaperone BiP (Fig. 4B, bottom). This HMW BiP-containing complex was remarkably resistant to detergent challenge (Fig. 4C) and its abundance increased significantly in tunicamycintreated cells (Figs. 4C-E, 6D-E [below]).

These findings allowed us to devise a simple assay for the HMW material by tracking the sedimentation of $\mathrm{BiP}$ from SDS-challenged whole-cell detergent lysates. These complexes are unlikely to be constituted exclusively from normally folding client proteins and chaperones, as overall protein biosynthesis decreases during ER stress. However, the abundance of these complexes is likely to depend on the supply of client proteins, as their abundance correlates with client synthesis being lower in $\mathrm{CHOP}^{-/-}$and GADD34 $4^{\Delta C / \Delta C}$ cells deficient in eIF2 $\alpha$ phosphatase activity (Figs. 4E, 6D [below]). Regardless of whether these complexes reflect abnormal conformations of client proteins or a normal phenomenon accentuated during ER stress, their reduced abundance in $\mathrm{CHOP}^{-/-}$and $G A D D 34^{\Delta C / \Delta C}$ cells suggests that the ER in these cells is experiencing stress differently from that of wild-type cells. To the extent that the treated mutant cells resemble more closely their untreated counterpart, we conclude that they are experiencing less stress than the wild-type cells, and suggest that this could be attributed to lower levels of ER client protein load in the mutant cells.

\section{GADD34 mutant animals are markedly protected from cell death caused by ER stress}

CHOP mutant animals and cells are partially protected from the lethal affects of ER stress. To determine whether impaired GADD34 expression plays a role in the protective effect of $C H O P$ deletion, we studied mice homozygous for the aforementioned mutation in $G A D D 34$, which eliminates the C-terminal domain required for GADD34-dependent phosphatase activity. 

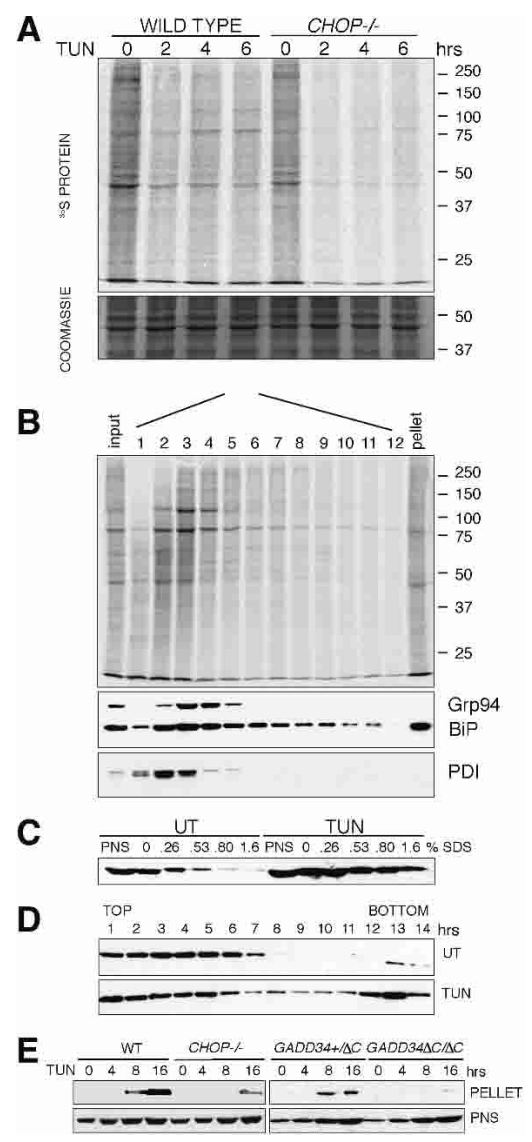

Figure 4. Enhanced recovery of client protein synthesis predisposes wild-type cells to accumulation of a high-molecularweight ER protein complex during ER stress. (A) Autoradiograph and Coomassie stain of gel of radiolabeled microsomal proteins isolated by flotation through sucrose from $\left[{ }^{35} \mathrm{~S}\right] \mathrm{methio-}$ nine pulse-labeled wild-type and $\mathrm{CHOP}^{-/-} \mathrm{MEFs}$ treated with $400 \mathrm{nM}$ thapsigargin. (B) Autoradiograph (top) and Grp94, BiP, and PDI immunoblots (bottom) of proteins from the wild-type 6-h time point of $A$ following velocity gradient centrifugation through a $10 \%-40 \%$ glycerol gradient. $(C) \mathrm{BiP}$ immunoblot from untreated and tunicamycin-treated $(2 \mu \mathrm{g} / \mathrm{mL}, 8 \mathrm{~h})$ wildtype cells. A total of $5 \%$ of the input, post-nuclear supernatant (PNS), or the pellet obtained from that post-nuclear supernatant treated with the indicated concentration of SDS and subjected to glycerol gradient centrifugation were loaded in each lane. $(D)$ Immunoblot of $\mathrm{BiP}$ from fractions taken through the glycerol gradient from a $0.8 \%$ SDS-treated sample as in $C$ (note that $\mathrm{BiP}$ migrating through the cushion as a large complex forms a distinct peak that is separated by a clear zone from the low-molecular-weight material). (E) Immunoblot of pelleted $\mathrm{BiP}$ (as in $D)$ and $5 \%$ of the input post-nuclear supernatant (PNS) BiP from untreated and tunicamycin treated wild-type, $\mathrm{CHOP}^{-/-}$and GADD34 mutant cells.

$G A D D 34^{\Delta C / \Delta C}$ mice are viable and fertile and otherwise indistinguishable from the wild type. Injection of a single dose of tunicamycin induces a highly characteristic renal lesion in mice, consisting of apoptosis of the renal tubular epithelium that is most conspicuous in the juxtamedullary region. This syndrome resembles acute tubular necrosis (ATN) in human and is likewise revers- ible over time (Zinszner et al. 1998). Wild-type mice uniformly exhibited these features of ATN, with conspicuous zonal drop-out of epithelial cells and accumulation of a large number of TUNEL-positive cells following tunicamycin injection. In contrast, $G A D D 34^{\Delta C / \Delta C}$ and $\mathrm{CHOP}^{-/-}$mice showed nearly complete protection from the development of this renal syndrome (Fig. 5). These experiments suggest that a significant portion of the protective effect of the CHOP mutation is mediated by loss of GADD34-mediated eIF2 $\alpha$-directed phosphatase activity.

Oxidizing conditions contribute to formation of HMW detergent-resistant stress-associated ER complex

ERO1 $\alpha$ induction by ER stress was also attenuated in $\mathrm{CHOP}^{-/-}$cells. Quantitative real-time PCR confirmed this observation and chromatin immunoprecipitation revealed the formation of a complex between CHOP protein and the ERO1 $\alpha$ promoter (Fig. 6A,B). These observations suggest that $\mathrm{ERO} 1 \alpha$, too, is a direct $\mathrm{CHOP}$ target gene. Unfortunately, the available antisera to mouse ERO1 $\alpha$ do not detect the endogenous protein, so we could not directly assess the impact of lowered ERO1 $\alpha$ mRNA levels on protein level in the mutant cells. Furthermore, cells have a second isoform, ERO1 $\beta$ (Pagani et al. 2000), whose induction by ER stress is unaffected by the CHOP mutation. However, even in stressed fibroblasts, ERO1 $\beta$ mRNA levels are $\sim 1 / 10$ those of ERO1 $\alpha$ (data not shown).

ERO1s oxidize protein disulfide isomerases (PDIs), which then transfer their S-S bonds to ER client proteins (Frand et al. 2000; Tu and Weissman 2004). The redox equilibrium in mammalian cells at steady-state maintains the majority of PDI in an oxidized form (Frand and Kaiser 1999; Fig. 6C); however, PDI can be reduced pharmacologically by treating cells briefly with dithiothreitol (DTT). The rate at which PDI is reoxidized following washout of the DTT provides a rough measure of ERO1 activity ( $\mathrm{Tu}$ et al. 2000). This simple assay was used to compare ERO1 activity in unstressed and stressed wild-type and $\mathrm{CHOP}^{-/-}$cells. In both genotypes, the detectable PDI is in its oxidized form basally (Fig. 6C). Treatment with DTT converts the high mobility, oxidized PDI to a lower mobility, reduced form. DTT washout leads to reoxidation of PDI, which is first manifest as a loss of the reduced form and only later as recovery of the oxidized form. The delay between the disappearance of reduced PDI and the recovery of its oxidized form is likely due to early formation of mixed disulfides between the newly oxidized PDI and the large amount of reduced client protein that accumulates in the ER of DTT-treated cells (Mezghrani et al. 2001); as disulfides reform in these clients, PDI is liberated and the steadystate of mostly oxidized PDI is re-established. The rate of PDI reoxidation revealed by this assay is considerably slower in $\mathrm{CHOP}^{-/-}$cells, consistent with a functional defect in ER oxidation.

If the hypo-oxidizing conditions in the $\mathrm{CHOP}^{-/-} \mathrm{ER}$ affect the detergent-resistant HMW complexes, we 
CHOP and ER stress

A

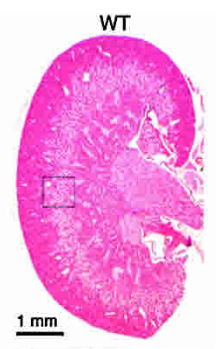

B

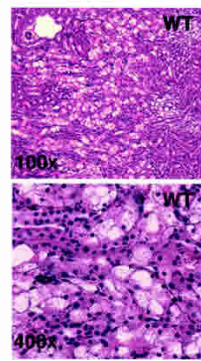

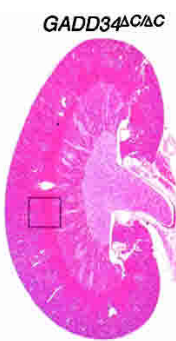

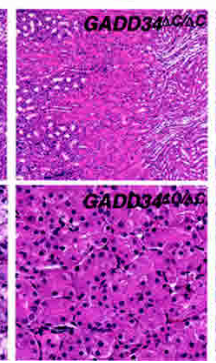

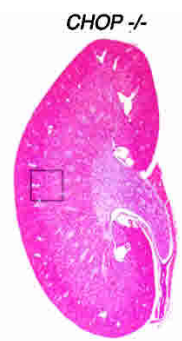

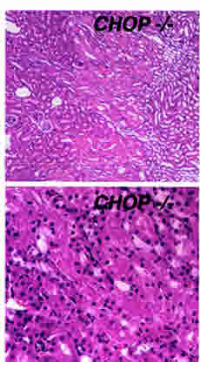

C

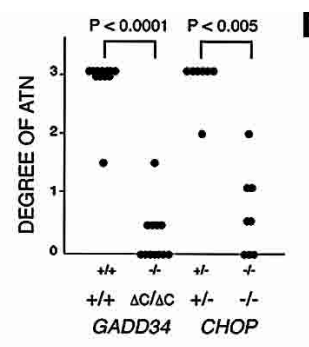

$\mathbf{E}$

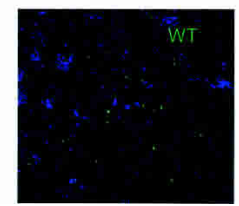

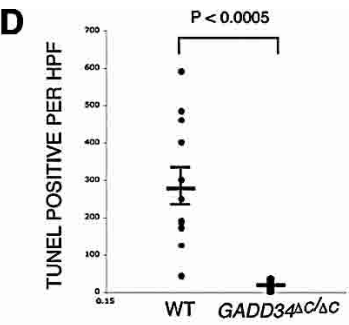

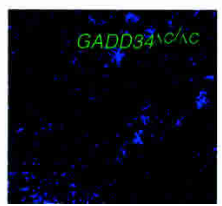

Figure 5. Loss of GADD34 phosphatase activity protects the renal epithelium from tunicamycin. $(A)$ Photomicrograhs $(10 \times)$ of wild-type, $G A D D 34^{\Delta C / \Delta C}$ and $C H O P^{-/-}$mouse kidneys stained with hematoxylin and eosin $96 \mathrm{~h}$ after injection with $1 \mu \mathrm{g} / \mathrm{gram}$ of tunicamycin. $(B)$ Photomicrographs $(100 \times$ and $400 \times)$ from the same sections. Note the extensive tubular-interstitial damage at the cortico-meduallary junction in the representative wild-type sample and its absence in the mutants. $(C)$ Quantification of tubularinterstitial damage at $96 \mathrm{~h}$ in tunicamycin-treated wild-type $(n=12$ animals $), G A D D 34^{\Delta C / \Delta C}(n=12), C H O P^{+/-}(n=8)$, and CHOP-/$(n=8)$. Grading by modified Shih scale (Shih et al. 1988) and $\mathrm{P}$ values calculated by a Mann-Whitney nonparametric test. (D) Quantification of cell death by counting TUNEL-positive cells per high-powered field (hpf) in kidneys from 12 wild-type and 12 $G A D D 34^{\Delta C / \Delta C}$ animals. The means of two fields per kidney of each animal are presented. The mean \pm SEM of each genotype is indicated by a horizontal bar and P values were calculated by 2-tail Student's $t$-test. $(E)$ Photomicrograph $(400 \times)$ of cortico-medullary junction of wild-type and GADD34 ${ }^{\Delta C / \Delta C}$ kidneys stained for TUNEL and counter-stained with Hoescht.

would expect to find some proteins whose incorporation into these complexes were redox dependent. Therefore, we compared the pattern of proteins recovered in these complexes by performing immunoblots on reducing and nonreducing SDS-PAGE. Pre-existing, glycosylated, Hsp47 and newly synthesized, nonglycosylated Hsp47 were both incorporated into the HMW complex in tunicamycin-treated cells; however, the levels of the latter were greater in wild-type than $\mathrm{CHOP}^{-/-}$cells (Fig. 6D, reducing gel). While the glycosylated Hsp47 is likely incorporated into HMW material as it associates with collagen fibrils (Nagata et al. 1986), the nonglycosylated Hsp47 is likely incorporated as a malfolded ER client protein; despite representing only a small fraction of total cellular Hsp47, the nonglycosylated form predominates in the HMW complex during ER stress (Fig. 6D, bottom).

As expected, immunoblot of the nonreducing gel revealed that most of the Hsp47 in the cell is in a reduced monomeric form; however, a substantial fraction of the nonglycosylated Hsp47 in the HMW complex was in a disulfide bond-stabilized complex resistant to boiling in SDS. This is reflected in the lower signal of the monomeric protein on the nonreducing compared with the reducing immunoblot and in the appearance of a high molecular weight species corresponding to an abnormal disulfide bond-stabilized Hsp47 complex (Fig. 6D, cf. left and right panels labeled PELLET). In both genotypes, tunicamycin led to accumulation of HMW complexes containing disulfide-bonded nonglycosylated Hsp47; how- ever, complex levels were higher in the wild type, implicating CHOP in redox control. Further support for a redox role in formation of the abnormal Hsp47 complex is provided by the observations that a mutant Cys138Ser Hsp47, which is unable to form S-S bonds, is not incorporated into the complex, and that expressing a dominant-negative ERO1 interferes with complex formation in the cell (Supplementary Fig. S2)

More BiP accumulated in the HMW complex in tunicamycin-treated wild-type than $\mathrm{CHOP}^{-/-}$cells; however, roughly equal amounts of (monomeric) BiP were detected in reducing and nonreducing immunoblots of the pellet (Fig. $6 \mathrm{D}$ ). This indicated that $\mathrm{BiP}$, a prominent constituent of the HMW complex, was not disulfide linked to itself or other proteins. In contrast, ex vivo treatment with DTT of detergent lysates from tunicamycin-treated wild-type cells markedly reduced the amount of BiP recovered in a HMW detergent-resistant form (Fig. 6E). This suggests that S-S bond formation between or within other proteins helps stabilize the BiP-containing HMW complex(es). Further evidence for the stabilizing effect of oxidation on the HMW BiP-containing complex was provided by challenging tunicamycin-treated cells with DTT, which markedly reduced the amount of BiP and nonglycosylated Hsp47 recovered in the HMW detergent-resistant material (Fig. 6F). DTT treatment disrupted these complexes at concentrations in which it had no measurable effect on protein synthesis, as reflected in the accumulation of newly synthesized nonglycosylated Hsp47 (Fig. 6F, bottom two panels, cf. lanes 
2 and 3,4$)$. At higher concentrations, translational repression by DTT and reduced client protein load may have also contributed to its inhibitory effect on HMW complex formation, as DTT also promotes ER stress and eIF2 $\alpha$ phosphorylation. These observations implicate the hypo-oxidizing conditions of the $\mathrm{CHOP}^{-/-} \mathrm{ER}$ in reduced formation of HMW disulfide-stabilized abnormal protein complexes.

Hypo-oxidizing conditions, elicited by ERO1 knockdown, protect against the lethal consequences of tunicamycin treatment

The observations noted above suggested that it might be possible to attenuate the lethal consequences of ER stress by manipulations that favor a hypo-oxidizing environment in the ER. Treatment of cells with low doses of reducing agents strongly protects against the lethal consequences of ER stress (Harding et al. 2003). However, it is not possible to distinguish between their effects in the ER and elsewhere. To address this issue more directly, we sought an experimental system to affect selectively and primarily redox in the ER. We were unable to affect consistently ER redox by RNAi of ERO1 in mammalian cells or to manipulate stably ERO1 activity

Figure 6. CHOP-dependent ERO1 $\alpha$ induction favors abnormal oxidized protein complexes. (A) Abundance of ERO1 $\alpha$ mRNA in untreated and tunicamycin-treated $(2 \mu \mathrm{g} / \mathrm{mL}, 8 \mathrm{~h})$ wild-type and $\mathrm{CHOP}^{-/-}$cells measured by quantitative real-time PCR and expressed as the ratio of EROl $\alpha$ mRNA to $\beta$ Actin mRNA. $(B)$ Chromatin immunoprecipitation of ERO1 $\alpha$ with anti-CHOP antiserum from untreated and tunicamycin-treated wild-type and $\mathrm{CHOP}^{-/-}$cells detected by a quantitative genomic PCR targeting the promoter region of ERO1 $\alpha$. The signal in the untreated $\mathrm{CHOP}^{-/-}$cells was arbitrarily assigned a value of $1 .(C)$ Immunoblot of PDI from untreated and tunicamycin-treated wild-type and $\mathrm{CHOP}^{-/-}$cells challenged in vivo with DTT and then chased in the absence of reducing agent for the indicated period of time before lysis in a nonreducing buffer. Identical samples were loaded on a reducing and nonreducing gel. The position of the low-mobility reduced form (RED) and highermobility oxidized form (OX) of PDI is indicated next to the nonreducing SDS-PAGE. An uncharacterized invariant band reactive with the PDI antibody is indicated by the asterisk. $(D)$ Immunoblot of Hsp47 and BiP in SDS-resistant HMW complexes (PELLET) and 5\% input post-nuclear supernatant (PNS) from wild-type and $\mathrm{CHOP}^{-/-}$cells treated with tunicamycin $(2$ $\mu \mathrm{g} / \mathrm{mL}$ ) for the indicated time. Identical samples were loaded on a reducing (left) and nonreducing (right) SDS-PAGE. The position of the Hsp47 disulfide-stabilized complex, glycosylated (G) and nonglycosylated $(\mathrm{O})$ monomer and $\mathrm{BiP}$ are indicated. $(E)$ Immunoblot of $\mathrm{BiP}$ in $\mathrm{HMW}$ complex pellet $(\mathrm{P})$ and supernatant (S) from untreated and tunicamycin-treated $(2 \mu \mathrm{g} / \mathrm{mL}, 8 \mathrm{~h})$ wildtype cells isolated by velocity centrifugation through $20 \%$ glycerol cushions containing $100 \mathrm{mM}$ DTT. $(F)$ Immunoblot of BiP and Hsp 47 in SDS-resistant HMW complex (PELLET) and 5\% input post-nuclear supernatant (PNS) from wild-type cells treated with tunicamycin $(2 \mu \mathrm{g} / \mathrm{mL})$ and the indicated concentrations of DTT in vivo for $8 \mathrm{~h}$. through interfering alleles in a relevant cell type. Therefore, we turned to the nematode Caenorhabditis elegans, which has a single ero-1 gene whose partial inactivation by RNA interference does not compromise animal viability. We therefore established conditions in which tunicamycin treatment reduced worm viability and compared the susceptibility of control, mock RNAi animals, and ero-1 RNAi animals with the lethal effects of tunicamycin.

Animals raised on ero-1 RNAi-expressing bacteria were remarkably resistant to tunicamycin; as the survival curves show, $>80 \%$ of mock RNAi animals exposed for $24 \mathrm{~h}$ to tunicamycin were dead $10 \mathrm{~d}$ later. Approximately $50 \%$ of the ero- 1 RNAi animals exposed to tunicamycin were dead at this time (Fig. 7A). As expected, ero-1 RNAi, like DTT and tunicamycin, activated the UPR, which is reflected in the induction of a transcriptional hsp-4::gfp (C. elegans BiP) reporter. Animals subjected to combined ero-1 RNAi and tunicamycin treatment had even higher levels of reporter induction, indicating that ero-1 RNAi did not suppress ER stress signaling (Fig. 7C).

The impact of ero-1 RNAi on survival of tunicamycintreated animals was very different from that of other genetic manipulations that cause ER stress. For example, inactivation of sel-1, a gene involved in degradation of
A

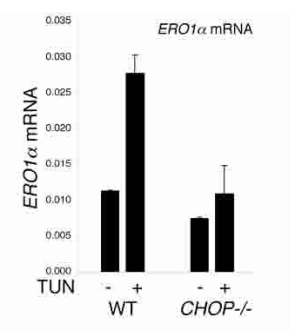

B

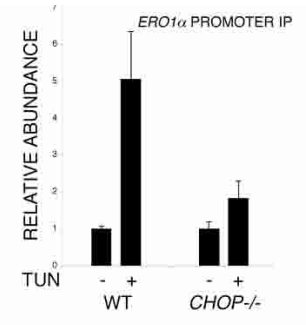

C

TUN

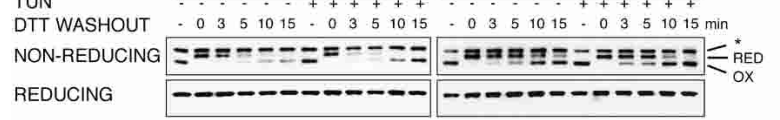

D

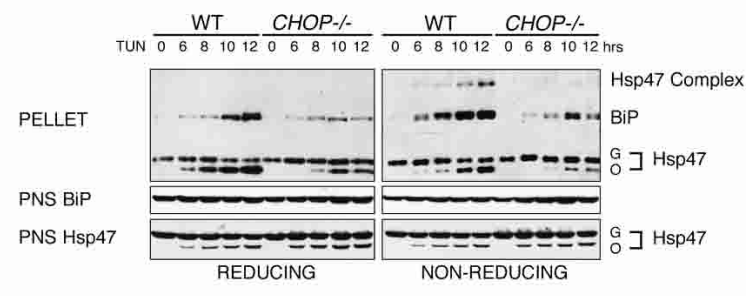

E

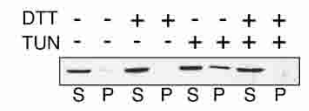

$\mathbf{F}$

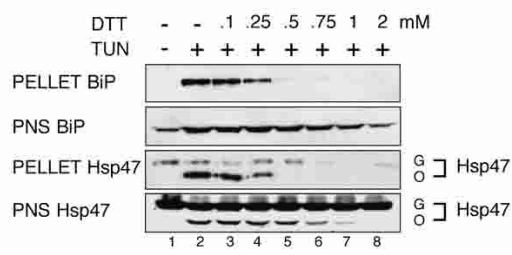


A

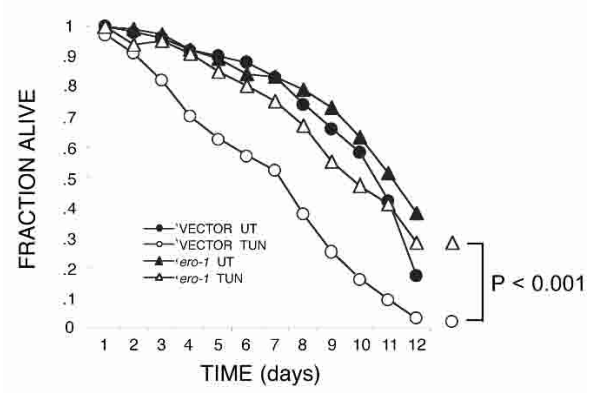

B

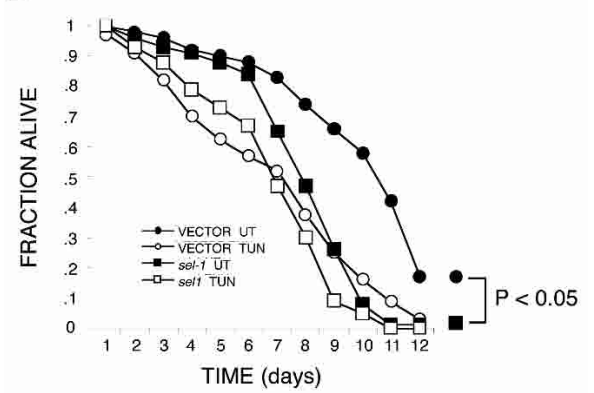

C

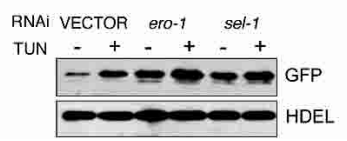

Figure 7. Knock-down of ero-1 in C. elegans is protective against the lethal effects of tunicamycin. Survival curves of young adult nematodes raised on mock RNAi, ero-1 RNAi, and sel-1 RNAi, and treated at day 0 with $30 \mu \mathrm{g} / \mathrm{mL}$ of tunicamycin for $24 \mathrm{~h}$. (A) Comparison of the mock RNAi and the ero-1 RNAi. Shown is a representative experiment $(n=3)$. $(B)$ Comparison of mock RNAi and sel-1 RNAi. The data in $A$ and $B$ are from the same experiment and are represented in two graphs for clarity. $P$ values for the divergence of the curves were determined using two-factor ANOVA analysis. (C) Immunoblot of lysates from hsp-4::gfp animals after growth on the indicated RNAi and treatment for $24 \mathrm{~h}$ with $30 \mu \mathrm{g} / \mathrm{mL}$ of tunicamycin. The GFP signal reflects activity of the UPR reporter, while the antiHDEL antibody detects an invariant $50-\mathrm{kDa}$ band used here as a loading control.

malfolded ER proteins, also activated the UPR reporter, but enhanced the toxicity of tunicamycin (Fig. 7B,C). This last observation indicates that the protective effect of ero-1 RNAi against the lethal consequences of tunicamycin exposure is unlikely to reflect trivial homologous preconditioning to ER stress. These observations indicate that under certain circumstances, a hypo-oxidizing ER is protective against the lethal consequences of ER stress.

\section{Discussion}

Our study has revealed a surprising role for the transcription factor CHOP in regulating ER client protein load and redox. By activating GADD34, CHOP promotes reversal of translational repression caused by the UPR-activated eIF2 $\alpha$ kinase PERK. The resurgent synthesis of ER client proteins contributes to ER stress in wild-type cells and its attenuation protects $\mathrm{CHOP}^{-/-}$and GADD34 mutant cells from death. By activating ERO1 $\alpha$, CHOP promotes oxidizing conditions in the ER, which contribute to death. These findings point to a prominent role for the transcription factor in regulating conditions in the ER itself that predispose stressed cells to death.

The GADD34 mutation strongly protects against tunicamycin-induced renal injury, whereas loss of GADD34-mediated translation recovery is detrimental to cultured fibroblasts treated with high doses of thapsigargin that profoundly inhibit protein synthesis (Novoa et al. 2003). In contrast, $C H O P$ deletion protects both the kidney and cultured fibroblasts against various inducers of ER stress (Zinszner et al. 1998). These differences point to the importance of context and signal strength to the function of the UPR. Cultured fibroblasts may more heavily depend on ongoing protein synthesis for their survival than the epithelial cells of the renal tubules, and thus require some GADD34 phosphatase activity, which $\mathrm{CHOP}^{-/-}$cells retain (Fig. 3A). Tubule cells might be especially sensitive to damage induced by malfolded client proteins, whose level is predicted to be lower in tunicamycin-treated GADD34 mutant mice than $\mathrm{CHOP}^{-/-}$mice. Furthermore, in addition to its impact on protein metabolism, reduced phosphatase activity enhances signaling in the eIF2 $\alpha$ phosphorylation-dependent integrated stress response, with significant pro-survival benefits (Jousse et al. 2003; Lu et al. 2004). Finally, GADD34 may have pro-apoptotic effects that are independent of its role as a component of an eIF2 $\alpha$ phosphatase complex (Yagi et al. 2003; Shi et al. 2004)

It had previously been shown that the ERO1 contributes significantly to the levels of reactive oxygen species in ER-stressed mammalian cells (Harding et al. 2003) and yeast (Haynes et al. 2004), and that the aforementioned integrated stress response mitigates this tendency (Harding et al. 2003; Tu and Weissman 2004). Activation of ERO1 $\alpha$ by CHOP might thus contribute to the CHOPdependent accumulation of reactive oxygen species in stressed cells (McCullough et al. 2001). Observations made here suggest that ER oxidation might also favor protein malfolding, as a more reducing ER was associated with lower levels of HMW detergent-resistant $\mathrm{BiP}$ and Hsp47-containing complexes. Similar complexes have been observed by others (Meunier et al. 2002), and while their precise nature and the degree to which they reflect the in vivo conformation of their constituents remains to be determined, their presence correlated with perturbed ER function and a predisposition to death in the system studied here. The role of ER oxidation in formation of such complexes might be mediated through abnormal stabilization of otherwise transient non-native disulfide bonds, which form abundantly in the ER, but are normally reduced or reshuffled (Jansens et al. 2002). Hyperoxidizing conditions might also attenuate retrotranslocation of malfolded proteins to the cytoplasm for 
degradation, as that process requires disulfide reduction (Tortorella et al. 1998; Fagioli et al. 2001).

The purpose of our study was to shed light on the role of CHOP in the ER stress-cell death connection. But viewed outside that context, the activities of $\mathrm{CHOP}$, revealed here, can also be rationalized as part of the cell's attempt to maintain and augment the capacity to synthesize and oxidize secreted proteins in the face of physiological load. Cells measure physiological ER stress to gauge the client protein load confronting their ER and adapt appropriately by up-regulating the enzymes required for organelle function, ERO1 being one such essential enzyme up-regulated by the UPR (Travers et al. 2000; Murray et al. 2004). PERK couples ER stress to translational repression. Its activity is highly adaptive for the individual secretory cell, but it comes with a cost to the organism, that is, a tendency toward less biosynthesis of secretory precursors and a potential for reduced secretory capacity. GADD34 expression, which we find to be CHOP dependent, offsets this tendency by restoring protein synthesis, and with it, presumably, secretory capacity.

The UPR has evolved considerably during phylogeny, a purely transcriptional response in unicellular organisms like yeast; a translational PERK-mediated component was acquired by simple metazoans, whereas in vertebrates, a GADD34-mediated mechanism to recover protein synthesis and secretory capacity was added (Harding et al. 2002). Here, we learn that CHOP, which is restricted to vertebrates, regulates the activity of this last adaptation and also contributes substantially to ERO1 activation. Therefore, the CHOP-mediated interplay between protein synthesis, oxidation, and cell death during ER stress more likely reflects a simple failure of homeostasis under extreme conditions than a feature of the UPR under positive selection. However, our findings also suggest that the set point for eIF2 $\alpha$ dephosphorylation and ERO1 activation by the UPR may be inappropriately low, and thus, compromise the viability of cells exposed to pathological conditions that perturb protein folding in the ER. It is tempting to speculate that judicious use of inhibitors of ERO1 and GADD34-PP1c enzyme complexes (inhibitors that have yet to be developed) may promote cell survival in pathophysiological states that compromise ER function

\section{Materials and methods}

Cell culture, treatment, immunoblotting, and immunoprecipitation

Wild-type, CHOP, and GADD34 mutant mouse embryonic fibroblasts were previously described (Zinszner et al. 1998; Novoa et al. 2003). Detection of CHOP, total eIF $2 \alpha$, phosphorylated eIF2 $\alpha$, ATF4, and GADD34 were as previously described (Harding et al. 2000a; Novoa et al. 2001), PDI was detected using a monoclonal antibody (SPA891, StressGen). BiP was detected using an anti-KDEL monoclonal antibody (SPA827, StressGen). Hsp47 was detected with a rabbit serum provided by Professor Kazuhiro Nagata (University of Kyoto, Japan). Metabolically labeled Hsp47 was detected by immunoprecipitation using the aforementioned antiserum. Metabolically labeled BiP was detected by immunoprecipitation using a polyclonal antiserum provided by Dr. Linda Hendershot (St. Jude, Memphis, TN).

To measure the oxidation state of PDI in vivo, cultured cells were treated with $10 \mathrm{mM}$ DTT for $30 \mathrm{~min}$ at $37^{\circ} \mathrm{C}$, washed, and returned to normal growth medium. At various times thereafter, samples were lysed in harvest buffer (Harding et al. 2000b) supplemented with $20 \mathrm{mM} \mathrm{N}$-ethylmaleimide, and $5 \mu \mathrm{g}$ of protein was loaded per lane on $14 \%$ SDS-polyacrylamide nonreducing gels to resolve the oxidized and reduced PDI species. A parallel reducing gel was used to control for total PDI levels.

\section{Array analysis}

Primary fibroblasts from two pairs of wild-type and two $\mathrm{CHOP}^{-/-}$sibling embryos at passage 3 were left untreated or treated with tunicamycin $(2 \mu \mathrm{g} / \mathrm{mL})$ for 4 or $8 \mathrm{~h}$ in duplicate $(24$ samples in all). Total RNA was isolated using the guanidine thiocyanate-acid-phenol extraction method. Fluorescent-labeled RNA probes for each of the samples were prepared and hybridized to Affymetrix mouse U74Av2 high-density oligonucleotide arrays as previously described (Lockhart et al. 1996). Primary image analysis of the arrays was performed using the Genechip 3.2 software package (Affymetrix). The raw data from the hybridization experiments were analyzed by GeneSpring. The raw signal from each gene was normalized to the mean strength of all genes from the same chip to obtain the normalized signal strength. Then, to allow visualization of all data on the same scale for subsequent analysis, the normalized signal strength of each gene was divided by the median signal strength for that gene among all samples to obtain the normalized expression level. Genes that had a raw signal strength of $>50$ and assigned a "present" signal flag (by the Genechip 3.2 software) were further analyzed. The complete data set has been submitted to the NCBI GEO database.

\section{Protein translation and HMW complex detection}

To measure translation of new proteins within the membrane fraction, which includes ER microsomes, cells were metabolically labeled for $30 \mathrm{~min}$ with $50 \mu \mathrm{Ci} / \mathrm{mL}^{35} \mathrm{~S}$-Translabel (ICN) as described previously (Harding et al. 1999). The dishes were flooded with ice-cold PBS containing $1 \mathrm{mM}$ cycloheximide and $20 \mathrm{mM}$ NEM to block further protein synthesis and prevent ex vivo protein oxidation. Following $5 \mathrm{~min}$ of incubation on ice, the plates were washed twice with homogenization buffer $(20$ $\mathrm{mM}$ HEPES at $\mathrm{pH} 7.5,1 \mathrm{mM}$ EDTA, $250 \mathrm{mM}$ sucrose) and disrupted using a ball-bearing homogenizer with a $16-\mu \mathrm{m}$ clearance (EMBL). The homogenate was adjusted to $2 \mathrm{M}$ sucrose and membranes were floated, by centrifugation, at $135,000 \mathrm{~g}$ for $3 \mathrm{~h}$, to the interface of $0.25 / 1.8 \mathrm{M}$ sucrose buffered with $20 \mathrm{mM}$ HEPES (pH 7.5) and $1 \mathrm{mM}$ EDTA. This membrane-enriched fraction was diluted 1:5 with homogenization buffer and microsomes pelleted at 100,000 $\mathrm{g}$ for $30 \mathrm{~min}$, followed by solubilization in buffer BP $(0.5 \%$ Triton X-100, 20 mM HEPES at $\mathrm{pH} 7.5$, $250 \mathrm{mM}$ sucrose, $100 \mathrm{mM} \mathrm{NaCl}, 2.5 \mathrm{mM} \mathrm{CaCl}_{2}$ ). This fraction was markedly enriched in the ER markers ribophorin I, BiP, and PDI, while being free of detectable GADD34 (data not shown) An equal amount of solubilized membrane protein $(15 \mu \mathrm{g})$ per lane was then analyzed by SDS-PAGE and autoradiography. In addition, $300 \mu \mathrm{g}$ of the 6-h wild-type sample were further analyzed by velocity gradient centrifugation through a $10 \%-30 \%$ linear glycerol gradient $(20 \mathrm{mM}$ HEPES at $\mathrm{pH} 7.9,150 \mathrm{mM}$ $\mathrm{NaCl}, 2.5 \mathrm{mM} \mathrm{CaCl}_{2}, 1.5 \mathrm{mM} \mathrm{MgCl}_{2}$ ) at 76,000g for $15 \mathrm{~h}$. Fractions were precipitated with trichloroacetic acid and separated 
by SDS-PAGE, half for autoradiography, and half for immunoblot.

For analysis of HMW complexes from whole-cell lysates, cultured cells were incubated for $5 \mathrm{~min}$ in ice-cold PBS containing $20 \mathrm{mM}$ NEM, prior to harvesting. A post-nuclear supernatant was prepared after lysis in buffer BP plus protease inhibitors. Equal amounts of protein, typically $1-1.5 \mathrm{mg}$, were adjusted to $0.8 \%$ SDS in $150 \mu \mathrm{L}$ of buffer BP. This was then layered upon a cushion of $20 \%$ glycerol, 20 mM HEPES (pH 7.5), $0.5 \%$ Triton $\mathrm{X}-100,0.8 \%$ SDS. Where indicated, $25 \mathrm{mM}$ DTT was included in the cushion. Samples were centrifuged at $100,000 \mathrm{~g}$ for $45 \mathrm{~min}$ at $4^{\circ} \mathrm{C}$. The resulting pellet was resuspended in urea loading buffer $(9.6 \mathrm{M}$ urea, $12 \%$ glycerol, $1.36 \%$ SDS, $40 \mathrm{mM}$ Tris at $\mathrm{pH}$ $6.8,0.002 \%$ bromophenol blue, with or without $100 \mathrm{mM}$ DTT as indicated), heated to $95^{\circ} \mathrm{C}$ for $5 \mathrm{~min}$, and separated by SDSPAGE for immunoblot. In experiments not shown, ATP was depleted by the addition of $100 \mathrm{U} / \mathrm{mL}$ hexokinase (Sigma) and 10 $\mathrm{mM}$ glucose to the lysis buffer; however, this did not affect the degree to which $\mathrm{BiP}$ localized to the pelleted material, suggesting that it represents an unusually stable interaction.

\section{PCR-based assay for XBP-1 splicing}

Total RNA was prepared from cells, and cDNA was synthesized from $2 \mu \mathrm{g}$ of each sample. This was used as template for PCR with primers flanking the splice site (see Supplemental Material for primer sequence and PCR conditions). Unspliced XBP-1 gave a product of $480 \mathrm{bp}$, and the spliced cDNA was $454 \mathrm{bp}$.

\section{Chromatin immunoprecipitation}

Formaldehyde was added directly to the cell culture medium to a final concentration of $1 \%$. Fixation was carried out at $22^{\circ} \mathrm{C}$ for $10 \mathrm{~min}$ prior to quenching with $0.125 \mathrm{M}$ glycine for $5 \mathrm{~min}$. Cells were lysed in triton harvest buffer containing protease inhibitors, and nuclei were pelleted at $1000 \mathrm{~g}$. The nuclear pellet was resuspended in RIPA buffer $(10 \mathrm{mM}$ Tris at $\mathrm{pH} 7.5,100 \mathrm{mM}$ $\mathrm{NaCl}, 1 \mathrm{mM}$ EDTA, $0.5 \%$ sodium deoxycholate, $0.1 \%$ SDS, $1 \%$ Triton X-100, protease inhibitors) and sonicated to an average fragment length of 500-1000 bp. The chromatin solution was precleared by centrifugation at $18,000 \mathrm{~g}$ for $10 \mathrm{~min}$, and then incubated overnight with anti-CHOP polyclonal antiserum or a no-antibody control. Chromatin-antibody complex was purified on protein A-Sepharose beads, which had been preblocked with $100 \mu \mathrm{g} / \mathrm{mL}$ sheared salmon sperm DNA. The beads were washed six times with RIPA buffer. The flow-thru of a no-antibody control IP was saved and used as input material for calibration of subsequent quantitative real-time PCR. Washed beads were treated with $200 \mu \mathrm{g} / \mathrm{mL}$ proteinase $\mathrm{K}$ in $10 \mathrm{mM}$ Tris at $\mathrm{pH} 8.0,1 \mathrm{mM}$ EDTA, $0.5 \%$ SDS at $55^{\circ} \mathrm{C}$ for $3 \mathrm{~h}$. The formaldehyde cross-links were reversed, and RNA removed by incubation at $65^{\circ} \mathrm{C}$ overnight. DNA was purified using QIAquick PCR purification columns (QIAGEN) and subjected to quantitative real-time PCR.

\section{Quantitative real-time PCR}

All quantitation was carried out using the MyIQ single-color real-time PCR detection system and IQ SYBR Green Supermix (Bio-Rad Laboratories). Template was prepared either from chromatin immunoprecipitates or by reverse transcription of $2 \mu \mathrm{g}$ of total RNA. All PCR reactions were performed in triplicate. The abundance of specific mRNAs was determined by comparison with a standard curve constructed by serial dilution of the sample and normalized for $\beta$ actin. The abundance of immunoprecipitated chromatin sequences was determined by compari- son to a standard curve constructed by serial dilution of input chromatin. The sequence of the primers used is provided in the Supplemental Material.

\section{Tunicamycin injection of mice and tissue sample analysis}

$\mathrm{CHOP}^{-/-}$mice lack the coding region of all but the $34 \mathrm{C}$-terminal amino acids of the protein, and the GADD34 mutationdeleting exon 3, which encodes the PP1c interaction domain, have been described (Zinszner et al. 1998; Novoa et al. 2003). C57BL/6 sibling mice (6- to 8-wk-old), matched for sex, but discordant for GADD34 or $C H O P$ genotype, were given a single $1-\mu \mathrm{g} /$ gram body weight intraperitoneal injection of tunicamycin in $200 \mu \mathrm{L}$ of $150 \mathrm{mM}$ dextrose. After $96 \mathrm{~h}$, they were sacrificed, and kidneys were processed as previously described (Zinszner et al. 1998). Acute tubular necrosis (ATN) within the juxtamedullary region was scored on a scale of from 0 to 3 : (0) no epithelial damage; (1) $<30 \%$ cells showing vacuolization/frank necrosis; (2) $30 \%-70 \%$ cells affected; and (3) $>70 \%$ cells affected (adapted from Shih et al. 1988). The results are expressed as the average of two blinded observers' scores. The interobserver discordance was never greater than one grade.

\section{Nematode experiments}

C. elegans culture techniques and strains have been described previously (Calfon et al. 2002), with the modification that exposure to tunicamycin was carried in liquid culture. Briefly, a synchronized clutch of $\sim 200$ larvae was grown on mock RNAi plates or plates seeded with HT115 Escherichia coli transformed with plasmids directing the expression of doublestranded RNA (so called RNAi feeding vectors) for ero-1 or sel-1. When the larvae reached the young adult stage $(\sim 4 \mathrm{~d}$ after hatching) the cohort was transferred to a flask of $S$ medium with or without tunicamycin, and the suspension culture was shaken for $24 \mathrm{~h}$ at room temperature. Following this exposure, the animals were transferred back to agar plates, and the viability of the cohort was assessed daily. Significance of survival curve deviation was determined using two-factor ANOVA analysis. GFP (directed by the resident $h s p-4:: g f p$ transgene) was detected by rabbit antiserum raised against bacterially expressed GFP, and an invariant $50-\mathrm{kDa}$ band was detected by an ant-HDEL monoclonal antibody as a loading control, a gift of Sean Monroe (University of Cambridge, UK).

\section{Acknowledgments}

We thank Roberto Sitia for the ERO1 expression plasmids, Linda Hendershot for polyclonal anti-BiP serum, and Sean Munroe for the anti-HDEL antibody. This work was supported by a Wellcome Trust International Research Fellowship and NIH grants ES08681 and DK47119. D.R. is a Scholar of the Ellison Medical Foundation.

\section{References}

Bertolotti, A., Zhang, Y., Hendershot, L., Harding, H., and Ron, D. 2000. Dynamic interaction of BiP and the ER stress transducers in the unfolded protein response. Nat. Cell. Biol. 2: 326-332.

Brush, M.H., Weiser, D.C., and Shenolikar, S. 2003. Growth arrest and DNA damage-inducible protein GADD34 targets protein phosphatase $1 \alpha$ to the endoplasmic reticulum and promotes dephosphorylation of the $\alpha$ subunit of eukaryotic translation initiation factor 2. Mol. Cell. Biol. 23: 12921303. 
Calfon, M., Zeng, H., Urano, F., Till, J.H., Hubbard, S.R., Harding, H.P., Clark, S.G., and Ron, D. 2002. IRE1 couples endoplasmic reticulum load to secretory capacity by processing the XBP-1 mRNA. Nature 415: 92-96.

Connor, J.H., Weiser, D.C., Li, S., Hallenbeck, J.M., and Shenolikar, S. 2001. Growth arrest and DNA damage-inducible protein gadd34 assembles a novel signaling complex containing protein phosphatase 1 and inhibitor 1. Mol. Cell. Biol. 21: 6841-6850.

Fagioli, C., Mezghrani, A., and Sitia, R. 2001. Reduction of interchain disulfide bonds precedes the dislocation of Ig- $\mu$ chains from the endoplasmic reticulum to the cytosol for proteasomal degradation. J. Biol. Chem. 276: 40962-40967.

Fawcett, T.W., Martindale, J.L., Guyton, K.Z., Hai, T., and Holbrook, N.J. 1999. Complexes containing activating transcription factor $(\mathrm{ATF}) / \mathrm{cAMP}$-responsive-element-binding protein (CREB) interact with the CCAAT/enhancer-binding protein (C/EBP)-ATF composite site to regulate Gadd153 expression during the stress response. Biochem. J. 339: 135-141.

Feng, B., Yao, P.M., Li, Y., Devlin, C.M., Zhang, D., Harding, H.P., Sweeney, M., Rong, J.X., Kuriakose, G., Fisher, E.A., et al. 2003. The endoplasmic reticulum as the site of cholesterol-induced cytotoxicity in macrophages. Nat. Cell. Biol. 5: 781-792.

Frand, A.R. and Kaiser, C.A. 1999. Erolp oxidizes protein disulfide isomerase in a pathway for disulfide bond formation in the endoplasmic reticulum. Mol. Cell 4: 469-477.

Frand, A.R., Cuozzo, J.W., and Kaiser, C.A. 2000. Pathways for protein disulphide bond formation. Trends Cell. Biol. 10: $203-210$.

Friedman, A.D. 1996. GADD153/CHOP, a DNA damage-inducible protein, reduced CAAT/enhancer binding protein activities and increased apoptosis in 32D c13 myeloid cells. Cancer Res. 56: 3250-3256.

Gow, A., Southwood, C.M., and Lazzarini, R.A. 1998. Disrupted proteolipid protein trafficking results in oligodendrocyte apoptosis in an animal model of Pelizaeus-Merzbacher disease. J. Cell. Biol. 140: 925-934.

Harding, H., Zhang, Y., and Ron, D. 1999. Translation and protein folding are coupled by an endoplasmic reticulum resident kinase. Nature 397: 271-274.

Harding, H., Novoa, I., Zhang, Y., Zeng, H., Wek, R.C., Schapira, M., and Ron, D. 2000a. Regulated translation initiation controls stress-induced gene expression in mammalian cells. Mol. Cell 6: 1099-1108.

Harding, H., Zhang, Y., Bertolotti, A., Zeng, H., and Ron, D. 2000b. Perk is essential for translational regulation and cell survival during the unfolded protein response. Mol. Cell 5: 897-904.

Harding, H., Zeng, H., Zhang, Y., Jungreis, R., Chung, P., Plesken, H., Sabatini, D., and Ron, D. 2001. Diabetes Mellitus and excocrine pancreatic dysfunction in Perk ${ }^{-/}$mice reveals a role for translational control in survival of secretory cells. Mol. Cell 7: 1153-1163.

Harding, H.P., Calfon, M., Urano, F., Novoa, I., and Ron, D. 2002. Transcriptional and translational control in the mammalian unfolded protein response. Annu. Rev. Cell. Dev. Biol. 18: 575-599.

Harding, H., Zhang, Y., Zeng, H., Novoa, I., Lu, P., Calfon, M., Sadri, N., Yun, C., Popko, B., Paules, R., et al. 2003. An integrated stress response regulates amino acid metabolism and resistance to oxidative stress. Mol. Cell 11: 619-633.

Haynes, C.M., Titus, E.A., and Cooper, A.A. 2004. Degradation of misfolded proteins prevents ER-derived oxidative stress and cell death. Mol. Cell 15: 767-776.

Jansens, A., van Duijn, E., and Braakman, I. 2002. Coordinated nonvectorial folding in a newly synthesized multidomain protein. Science 298: 2401-2403.

Jordan, R., Wang, L., Graczyk, T.M., Block, T.M., and Romano, P.R. 2002. Replication of a cytopathic strain of bovine viral diarrhea virus activates PERK and induces endoplasmic reticulum stress-mediated apoptosis of MDBK cells. J. Virol. 76: $9588-9599$.

Jousse, C., Oyadomari, S., Novoa, I., Lu, P.D., Zhang, Y., Harding, H.P., and Ron, D. 2003. Inhibition of a constitutive translation initiation factor $2 \alpha$ phosphatase, $\mathrm{CReP}$, promotes survival of stressed cells. J. Cell. Biol. 163: 767-775.

Kaufman, R.J. 1999. Stress signaling from the lumen of the endoplasmic reticulum: Coordination of gene transcriptional and translational controls. Genes \& Dev. 13: 1211-1233.

- 2002. Orchestrating the unfolded protein response in health and disease. J. Clin. Invest. 110: 1389-1398.

Kumar, R., Azam, S., Sullivan, J., Owen, C., Cavener, D., Zhang, P., Ron, D., Harding, H., Chen, J., Han, A., et al. 2001. Brain ischemia and reperfusion activates the eukaryotic initiation factor $2 \alpha$ kinase, PERK. J. Neurochem. 77: 1418-1421.

Lockhart, D.J., Dong, H., Byrne, M.C., Follettie, M.T., Gallo, M.V., Chee, M.S., Mittmann, M., Wang, C., Kobayashi, M., Horton, H., et al. 1996. Expression monitoring by hybridization to high-density oligonucleotide arrays. Nat. Biotechnol. 14: $1675-1680$.

Lu, P.D., Jousse, C., Marciniak, S.J., Zhang, Y., Novoa, I., Scheuner, D., Kaufman, R.J., Ron, D., and Harding, H.P. 2004. Cytoprotection by pre-emptive conditional phosphorylation of translation initiation factor 2. EMBO $J$. 23: 169-179.

Ma, Y. and Hendershot, L.M. 2003. Delineation of a negative feedback regulatory loop that controls protein translation during endoplasmic reticulum stress. J. Biol. Chem. 278: 34864-34873.

Ma, Y., Brewer, J.W., Diehl, J.A., and Hendershot, L.M. 2002. Two distinct stress signaling pathways converge upon the CHOP promoter during the mammalian unfolded protein response. J. Mol. Biol. 318: 1351-1365.

McCullough, K.D., Martindale, J.L., Klotz, L.O., Aw, T.Y., and Holbrook, N.J. 2001. Gadd153 sensitizes cells to endoplasmic reticulum stress by down-regulating $\mathrm{Bcl} 2$ and perturbing the cellular redox state. Mol. Cell. Biol. 21: 1249-1259.

Meunier, L., Usherwood, Y.K., Chung, K.T., and Hendershot, L.M. 2002. A subset of chaperones and folding enzymes form multiprotein complexes in endoplasmic reticulum to bind nascent proteins. Mol. Biol. Cell 13: 4456-4469.

Mezghrani, A., Fassio, A., Benham, A., Simmen, T., Braakman, I., and Sitia, R. 2001. Manipulation of oxidative protein folding and PDI redox state in mammalian cells. EMBO $J$. 20: 6288-6296.

Murray, J.I., Whitfield, M.L., Trinklein, N.D., Myers, R.M., Brown, P.O., and Botstein, D. 2004. Diverse and specific gene expression responses to stresses in cultured human cells. Mol. Biol. Cell 15: 2361-2374.

Nagata, K., Saga, S., and Yamada, K.M. 1986. A major collagenbinding protein of chick embryo fibroblasts is a novel heat shock protein. J. Cell. Biol. 103: 223-229.

Nakagawa, T., Zhu, H., Morishima, N., Li, E., Xu, J., Yankner, B.A., and Yuan, J. 2000. Caspase-12 mediates endoplasmicreticulum-specific apoptosis and cytotoxicity by amyloid- $\beta$. Nature 403: 98-103.

Novoa, I., Zeng, H., Harding, H., and Ron, D. 2001. Feedback inhibition of the unfolded protein response by GADD34mediated dephosphorylation of eIF $2 \alpha$. J. Cell. Biol. 153: 1011-1022. 
Novoa, I., Zhang, Y., Zeng, H., Jungreis, R., Harding, H.P., and Ron, D. 2003. Stress-induced gene expression requires programmed recovery from translational repression. EMBO $\mathrm{J}$. 22: 1180-1187.

Oyadomari, S., Araki, E., and Mori, M. 2002a. Endoplasmic reticulum stress-mediated apoptosis in pancreatic $\beta$-cells. Apoptosis 7: 335-345.

Oyadomari, S., Koizumi, A., Takeda, K., Gotoh, T., Akira, S., Araki, E., and Mori, M. 2002b. Targeted disruption of the Chop gene delays endoplasmic reticulum stress-mediated diabetes. J. Clin. Invest. 109: 525-532.

Pagani, M., Fabbri, M., Benedetti, C., Fassio, A., Pilati, S., Bulleid, N.J., Cabibbo, A., and Sitia, R. 2000. Endoplasmic reticulum oxidoreductin 1-1 $\beta$ (ERO1-L $\beta$ ), a human gene induced in the course of the unfolded protein response. J. Biol. Chem. 275: 23685-23692.

Paschen, W. and Doutheil, J. 1999. Disturbances of the functioning of endoplasmic reticulum: A key mechanism underlying neuronal cell injury? J. Cereb. Blood Flow Metab. 19: $1-18$.

Patil, C. and Walter, P. 2001. Intracellular signaling from the endoplasmic reticulum to the nucleus: The unfolded protein response in yeast and mammals. Curr. Opin. Cell. Biol. 13: 349-355.

Rao, R.V., Hermel, E., Castro-Obregon, S., del Rio, G., Ellerby, L.M., Ellerby, H.M., and Bredesen, D.E. 2001. Coupling endoplasmic reticulum stress to the cell death program. Mechanism of caspase activation. J. Biol. Chem. 276: 3386933874.

Scheuner, D., Song, B., McEwen, E., Gillespie, P., Saunders, T., Bonner-Weir, S., and Kaufman, R.J. 2001. Translational control is required for the unfolded protein response and in-vivo glucose homeostasis. Mol. Cell 7: 1165-1176.

Shen, X., Ellis, R.E., Lee, K., Liu, C.-Y., Yang, K., Solomon, A., Yoshida, H., Morimoto, R., Kurnit, D.M., Mori, K., et al. 2001. Complementary signaling pathways regulate the unfolded protein response and are required for C. elegans development. Cell 107: 893-903.

Shi, W., Sun, C., He, B., Xiong, W., Shi, X., Yao, D., and Cao, X. 2004. GADD34-PP1c recruited by Smad7 dephosphorylates TGF $\beta$ type I receptor. J. Cell. Biol. 164: 291-300.

Shih, W., Hines, W.H., and Neilson, E.G. 1988. Effects of cyclosporin A on the development of immune-mediated interstitial nephritis. Kidney Int. 33: 1113-1118.

Sok, J., Wang, X.Z., Batchvarova, N., Kuroda, M., Harding, H., and Ron, D. 1999. CHOP-dependent stress-inducible expression of a novel form of carbonic anhydrase VI. Mol. Cell. Biol. 19: 495-504.

Su, H.L., Liao, C.L., and Lin, Y.L. 2002. Japanese encephalitis virus infection initiates endoplasmic reticulum stress and an unfolded protein response. J. Virol. 76: 4162-4171.

Tortorella, D., Story, C.M., Huppa, J.B., Wiertz, E.J., Jones, T.R., Bacik, I., Bennink, J.R., Yewdell, J.W., and Ploegh, H.L. 1998. Dislocation of type I membrane proteins from the ER to the cytosol is sensitive to changes in redox potential. J. Cell. Biol. 142: 365-376.

Travers, K.J., Patil, C.K., Wodicka, L., Lockhart, D.J., Weissman, J.S., and Walter, P. 2000. Functional and genomic analyses reveal an essential coordination between the unfolded protein response and ER-associated degradation. Cell 101: 249258.

$\mathrm{Tu}$, B.P. and Weissman, J.S. 2004. Oxidative protein folding in eukaryotes: Mechanisms and consequences. J. Cell. Biol. 164: 341-346.

Tu, B.P., Ho-Schleyer, S.C., Travers, K.J., and Weissman, J.S.
2000. Biochemical basis of oxidative protein folding in the endoplasmic reticulum. Science 290: 1571-1574.

Ubeda, M., Wang, X.-Z., Zinszner, H., Wu, I., Habener, J., and Ron, D. 1996. Stress-induced binding of transcription factor CHOP to a novel DNA-control element. Mol. Cell. Biol. 16: $1479-1489$.

Wang, X.-Z. and Ron, D. 1996. Stress-induced phosphorylation and activation of the transcription factor CHOP (GADD153) by p38 MAP-kinase. Science 272: 1347-1349.

Wang, X.-Z., Kuroda, M., Sok, J., Batchvarova, N., Kimmel, R., Chung, P., Zinszner, H., and Ron, D. 1998a. Identification of novel stress-induced genes downstream of chop. EMBO $\mathrm{J}$. 17: 3619-3630.

Wang, X.Z., Harding, H.P., Zhang, Y., Jolicoeur, E.M., Kuroda, M., and Ron, D. 1998b. Cloning of mammalian Ire1 reveals diversity in the ER stress responses. EMBO J. 17: 5708-5717.

Wei, M.C., Zong, W.X., Cheng, E.H., Lindsten, T., Panoutsakopoulou, V., Ross, A.J., Roth, K.A., MacGregor, G.R., Thompson, C.B., and Korsmeyer, S.J. 2001. Proapoptotic BAX and BAK: A requisite gateway to mitochondrial dysfunction and death. Science 292: 727-730.

Yagi, A., Hasegawa, Y., Xiao, H., Haneda, M., Kojima, E., Nishikimi, A., Hasegawa, T., Shimokata, K., and Isobe, K. 2003. GADD34 induces p53 phosphorylation and p21/WAF1 transcription. J. Cell. Biochem. 90: 1242-1249.

Yoshida, H., Okada, T., Haze, K., Yanagi, H., Yura, T., Negishi, M., and Mori, K. 2000. ATF6 activated by proteolysis binds in the presence of NF-Y (CBF) directly to the cis-acting element responsible for the mammalian unfolded protein response. Mol. Cell. Biol. 20: 6755-6767.

Yoshida, H., Matsui, T., Yamamoto, A., Okada, T., and Mori, K. 2001. XBP1 mRNA is induced by ATF6 and spliced by IRE1 in response to ER stress to produce a highly active transcription factor. Cell 107: 881-891.

Zhan, Q., Lord, K.A., Alamo Jr., I., Hollander, M.C., Carrier, F., Ron, D., Kohn, K.W., Hoffman, B., Liebermann, D.A., and Fornace Jr., A.J. 1994. The gadd and MyD genes define a novel set of mammalian genes encoding acidic proteins that synergistically suppress cell growth. Mol. Cell. Biol. 14: 2361-2371.

Zhang, P., McGrath, B., Li, S., Frank, A., Zambito, F., Reinert, J., Gannon, M., Ma, K., McNaughton, K., and Cavener, D.R. 2002. The PERK eukaryotic initiation factor $2 \alpha$ kinase is required for the development of the skeletal system, postnatal growth, and the function and viability of the pancreas. Mol. Cell. Biol. 22: 3864-3874.

Zinszner, H., Kuroda, M., Wang, X., Batchvarova, N., Lightfoot, R.T., Remotti, H., Stevens, J.L., and Ron, D. 1998. CHOP is implicated in programmed cell death in response to impaired function of the endoplasmic reticulum. Genes \& Dev. 12: 982-995. 


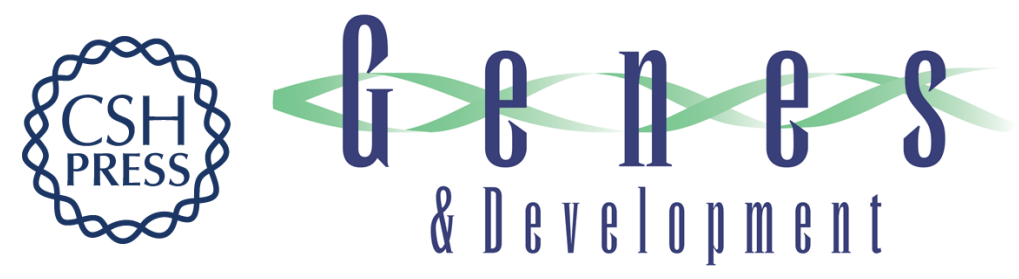

\section{CHOP induces death by promoting protein synthesis and oxidation in the stressed endoplasmic reticulum}

Stefan J. Marciniak, Chi Y. Yun, Seiichi Oyadomari, et al.

Genes Dev. 2004, 18:

Access the most recent version at doi:10.1101/gad.1250704

Supplemental
Material http://genesdev.cshlp.org/content/suppl/2004/11/23/18.24.3066.DC1

References This article cites 62 articles, 35 of which can be accessed free at:

http://genesdev.cshlp.org/content/18/24/3066.full.html\#ref-list-1

License

Email Alerting

Receive free email alerts when new articles cite this article - sign up in the box at the top

Service

right corner of the article or click here.

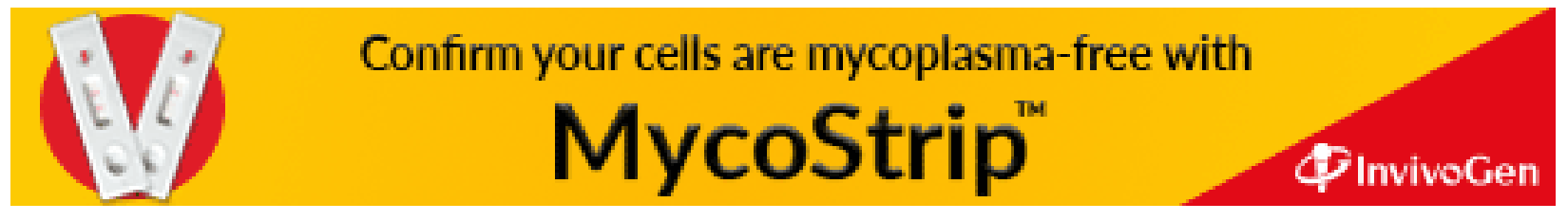

